\title{
Pengaruh Tingkat Keseriusan Kecurangan, Personal Cost, dan Komitmen Organisasi terhadap Kecenderungan Melakukan Whistleblowing
}

\author{
Nur Fauziah Busra, Muhammad Ahyaruddin, Agustiawan \\ Fakultas Ekonomi dan Bisnis, Universitas Muhammadiyah Riau, Pekanbaru, Indonesia \\ Email: fauziahbusra14@gmail.com
}

\section{A R T I C L E I N F O}

Article History:

Received: 16 October 2019

Accepted: 31 October 2019

Available online: 12 November

2019

Keywords:

Severity of Fraud

Personal Cost

Organizational Commitment

Whistleblowing

\begin{abstract}
A B S T R A C T
This study aims to investigate the factors that influence an individual's tendency to whistleblowing. Specifically, this study focuses the effect of severity offraud, personal cost and organizational commitment on tendency to whistleblowing. The sample of this study are civil servants of Regional Development Planning Agency (BAPPEDA) of Pekanbaru city. This study uses questionnaire to collect the data and uses multiple regression to test the hypothesis. The results of study showed that severity of fraud and organizational commitment have significantly effect on tendency to whistleblowing. But, this study did not find significant effect among personal cost and tendency to whistleblowing. This means that the civil servants do not consider personal cost as a factor that will influence their intention to take or not take whistleblowing.
\end{abstract}

\section{Pendahuluan}

Jumlah tindak kecurangan yang terjadi beberapa tahun belakangan ini baik di organisasi swasta maupun organisasi sektor publik mengalami peningkatan (Ahyaruddin \& Asnawi, 2017). Indonesia Corruption Watch (ICW) menyatakan bahwa organisasi sektor publik merupakan sektor yang paling rentan melakukan tindakan korupsi. Pada tahun 2016 terdapat kerugian negara sebesar Rp 1,5 triliun dalam 482 kasus korupsi dengan jumlah tersangka 1.101 orang dan mengalami kenaikan pada tahun 2017 kerugian negara sebesar Rp 6,5 triliun sebanyak 576 kasus korupsi dengan jumlah tersangka 1.298 orang (Indonesia Corruption Watch, 2017). Kondisi ini mengambarkan bahwa kasus korupsi yang melibatkan aparat sipil negara di Indonesia mengalami kenaikan dari tahun sebelumnya.
Banyaknya kasus korupsi yang terjadi khususnya pada sektor publik merupakan sebuah bentuk kejahatan luar biasa, karena efek korupsi yang dihasilkan bukan hanya kehilangan banyak uang tetapi berdampak terhadap kondisi perekonomian. Salah satu cara yang paling efektif dalam memberantas korupsi adalah memberdayakan peran whistleblower. Menurut laporan Association of Certified Fraud Examiner (ACFE), tingkat persentase pengungkapan kecurangan yang dilakukan oleh whistleblower sangat tinggi yaitu $47,5 \%$. Hal ini mengindikasikan bahwa hampir setengah dari kasus kecurangan diungkapkan oleh whistleblowers. Namun menjadi seorang whistleblowers bukan hal yang mudah. Seseorang yang berasal dari internal organisasi umumnya akan menghadapi dilema etis dalam memutuskan apakah harus 
"meniup peluit" atau membiarkannya tetap tersembunyi (Bagustianto dan Nurkholis, 2015). Oleh karena itu topik terkait pemahaman faktor-faktor yang mempengaruhi niat pegawai untuk melakukan whistleblowing sangat penting untuk diteliti agar dapat membantu organisasi merancang kebijakan sistem whistleblowing yang paling efektif.

Beberapa faktor yang mungkin mempengaruhi niat melakukan whistleblowing adalah tingkat keseriusan kecurangan, personal cost dan komitmen organisasi. Salah satu hasil penelitian yang setuju bahwa tingkat keeriusan berpengaruh terhadap whistleblowing adalah Near dan Miceli (1985) yang menyatakan bahwa ketika ada anggota organisasi yang mengetahui ataupun mengamati adanya tindakan kecurangan, terlebih jika tindakan kecurangan itu bersifat serius, maka ia akan lebih cenderung melakukan whistleblowing. Sedangkan personal cost menurut penelitian Liyanarachchi dan Newdick (2009) menyatakan bahwa kekuatan pembalasan dapat mempengaruhi kecenderungan orang untuk melaporkan tindakan pelanggaran. Faktor terakhir yang mungkin memiliki pengaruh terhadap whistleblowing adalah komitmen organisasi. Bentuk loyalitas dari pegawai, ketika ada tindakan kecurangan yang dilakukan oleh salah satu anggota organisasi maka niat untuk melakukan whistleblowing akan tinggi karena mereka tidak ingin melihat organisasinya hancur.

Menurut Brief dan Motowidlo (1986), whistleblowing merupakan salah satu bentuk tindakan prososial anggota organisasi untuk menyampaikan arahan, prosedur, atau kebijakan yang menurutnya mungkin tidak etis, ilegal atau membawa bencana bagi tujuan jangka panjang organisasi kepada individu atau badan lainnya yang memiliki posisi untuk melakukan tindakan korektif. Dalam hal ini prosocial organizational behavior theory telah menegaskan bahwa tindakan whistleblowing seorang pegawai menunjukkan bentuk komitmen pegawai tersebut untuk melindungi organisasinya dari ancaman hal-hal yang tidak etis atau ilegal.

Berdasarkan penjelasan tersebut, penelitian ini bertujuan untuk menguji faktor-faktor yang mempengaruhi niat pegawai untuk melakukan whistleblowing. Secara khusus penelitian ini menguji pengaruh tingkat keseriusan kecurangan, personal cost, dan komitmen organisasi terhadap niat melakukan whistleblowing. Penelitian ini merupakan modifikasi dan pengembangan dari penelitian sebelumnya terkait faktor-faktor yang mempengaruhi whistleblowing yang cenderung mendapatkan hasil yang inkonsisten, misalnya penelitian Aliyah (2015); Abdullah (2017); dan Bagustianto dan Nurkholis (2015). Penelitian ini berfokus pada Badan Perencanaan Pembangunan Daerah yang memang sering terjadi kasus tindakan kecurangan di bidang Perencanaan Pembangunan. Hasil penelitian ini diharapkan bisa memberikan kontribusi dalam pengembangan literatur serta memberikan implikasi praktis kepada organisasi sektor publik untuk membuat sebuah kebijakan tentang whistleblowing system agar kecurangan yang selama ini terjadi bisa diungkap.

Secara keseluruhan, penelitian ini ditulis dalam beberapa bagian berikut: pertama, artikel ini menjelaskan tentang permasalahan dan konteks penelitian yang dituangkan dalam bagian pendahuluan. Kemudian pada bagian selanjutnya menjelaskan tentang tinjauan pustaka dengan pengembangan hipotesis, metode penelitian yang digunakan, hasil serta pembahasan. Pada bagian terakhir menyajikan kesimpulan, keterbatasan dan saran untuk penelitian selanjutnya.

\section{Tinjauan Pustaka dan Pengembangan Hipotesis}

\subsection{Prosocial Organizational Behavior} Theory

Prosocial organizational behavior theory sebagai perilaku/tindakan yang dilakukan oleh anggota sebuah organisasi terhadap individu, kelompok, atau organisasi yang ditunjuk untuk meningkatkan kesajahteraan individu, kelompok, atau organisasi tersebut (Brief dan Motowidlo, 1986). Menurut Dozier dan Miceli (1985) bahwa perilaku prososial adalah perilaku sosial positif yang dimaksudkan untuk memberikan manfaat pada orang lain. Perilaku prososial tidak sama dengan altruisme, pelaku prososial juga dapat 
memiliki maksud untuk mendapatkan manfaat untuk dirinya.

Menurut Brief dan Motowidlo (1986) menyatakan bahwa whistleblowing adalah salah satu bentuk prosocial organizational behavior. Pendapat ini sejalan dengan Dozier dan Miceli (1985) yang menyatakan bahwa tindakan whistleblowing adalah salah satu perilaku prososial karena secara umum tindakan whistleblowing akan memberikan manfaat bagi organisasi maupun pelapor dari kecurangan.

Banyak peneliti mengkaitkan Prosocial organizational behavior theory untuk mendukung terjadinya Whistleblowing. salah satunya penelitian Dozier dan Miceli (1985) menyatakan bahwa tindakan whistleblowing merupakan perilaku prososial, karena perilaku prososial adalah perilaku yang memberiakan manfaat bagi orang lain (organisasi) dan memberikan manfaat/keuntungan juga bagi whistleblower. Hal ini diperkuat dengan Brief dan Motowidlo (1986) menyebutkan whistleblowing sebagai salah satu dari tiga belas bentuk prosocial organizational behavior.

Dua kelompok besar variabel anteseden yang dimilki oleh prosocial organizational behavior. Pertama, individual anteseden, merupakan aspek yang berasal dari individu pelaku tindakan prososial seperti kemampuan individu menginternalisasi standar keadilan, tanggung jawab individu terhadap lingkungan sosial, cara penalaran moral dan perasaan empati terhadap orang lain. Kedua, kontekstual anteseden, merupakan aspek dari konteks organisasi dan lingkungan kerja seperti faktor norma, kohesivitas kelompok, panutan, gaya kepemimpinan, iklim organisasi, tekanan, komitmen organisasi, dan hal-hal lain yang dapat memengaruhi suasana hati, rasa kepuasan atau ketidakpuasan (Brief dan Motowidlo, 1986).

\subsection{Pengaruh Tingkat Keseriusan Kecurangan terhadap Niat Melakukan Whistleblowing}

Organisasi akan berdampak buruk atas tindak kecurangan yang lebih serius dari pada kecurangan yang kurang serius. Apabila pegawai melihat adanya dugaan kecurangan yang berdampak buruk atas organisasinya, maka akan tumbuh niat untuk melakukan whistleblowing. Namun pandangan tiap anggota organisasi terhadap tingkat keseriusan kecurangan dapat saja berbeda antara satu dengan yang lainya. Terkadang pegawai yang melihat adanya tindakan kecurangan yang merugikan organisasi sebesar RP. 50.000.000,00 sudah merasakan bahwa itu sangat merugikan organisasi, tapi berbeda dengan pandangan pegawai yang lainya, yang berpendapat bahwa itu belum terlalu berdampak buruk terhadap organisasi. Penelitian yang dilakukan oleh Abdullah (2017) dan Setyawati et al. (2015) menunjukan bahwa tingkat keseriusan kecurangan berpengaruh terhadap niat seseorang untuk melakukan whistleblowing.

Penelitian terdahulu banyak mengacu pada theory planned behavior yang dikembangkan oleh Ajzen (1991). Salah satu penelitian Winardi (2013) menjelaskan tingkat keseriusan kecurangan dapat mempengaruhi niat melakukan whistleblowing dengan mengunakan theory planned behavior. Menurut Ajzen (1991), niat diasumsikan untuk menangkap faktor motivasi yang mempengaruhi sebuah perilaku, yang ditunjukkan oleh seberapa keras usaha yang direncanakan seorang individu untuk mencoba melakukan perilaku tersebut. Oleh karena itu berdasarkan theory planned behavior tersebut niat dijadikan sebagai faktor untuk memprediksi tindakan whistleblowing. Maka hipotesis pertama yang diajukan dalam penelitian ini adalah:

H1. Diduga Tingkat keseriusan kecurangan berpengaruh positif terhadap niat melakukan whistleblowing

\subsection{Pengaruh Personal Cost terhadap Niat Melakukan Whistleblowing}

Semakin besar persepsi personal cost seseorang maka akan semakin berkurang niat orang tersebut untuk melakukan tindakan whistleblowing. Misalnya ada pegawai yang melihat adanya tindakan dugaan kecurangan kemudian ada niat untuk melakukan whistleblowing namun niat tersebut dipengaruhi terhadap pandangan akan adanya pembalasan terhadap pelaporan yang dilakukan pegawai tersebut. Sejalan dengan penelitian Septianti (2013) yang menyatakan bahwa Personal cost merupakan salah satu 
alasan utama yang menyebabkan seseorang tidak ingin melaporkan dugaan kecurangan karena mereka meyakini bahwa laporan mereka tidak akan ditindak lanjuti, mereka akan mengalami retaliasi, atau manajemen tidak akan melindungi mereka dari ancaman retaliasi, khususnya dalam jenis pelanggaran yang melibatkan para manajer. Penelitian yang dilakukan oleh Aliyah (2015) dan Setyawati et al. (2015) menunjukan bahwa personal cost berpengaruh terhadap niat seseorang untuk melakukan whistleblowing. Personal cost dianggap cocok mempengaruhi niat melakukan whistleblowing karena semakin besar persepsi personal cost, maka semakin rendah niat untuk melaporkan tindakan kecurangan. Berdasarkan hasil penelitian sebelumnya, maka hipotesis kedua yang diajukan adalah:

H2. Personal Cost berpengaruh negatif terhadap niat melakukan whistleblowing.

\subsection{Pengaruh Komitmen Organisasi terhadap Niat Melakukan Whistleblowing}

Dalam suatu organisasi swasta maupun organisasi sektor publik sangat diperlukan pegawai yang memiliki komitmen yang tinggi terhadap organisasinya. Komitmen organisasi bisa diartikan dengan kecintaan pegawai terhadap organisasinya, melakukan pekerjaan dengan semaksimal mungkin sehingga tujuan organisasi tercapai. Apabila seorang pegawai memiliki komitmen yang tinggi terhadap pekerjaan dan organisasinya maka akan tumbuh rasa ingin meningkatkan kesejahteraan dan keberhasilan organsisai. Jika ada Pegawai yang melihat adanya tindakan kecurangan yang dapat menganggu keberhasilan tujuan organsiasi maka pegawai akan senantiasa mengungkapkannya. Penelitian yang dilakukan oleh Bagustianto dan Nurkholis (2015) dan Setyawati et al. (2015) menunjukan bahwa komitmen organisasi berpengaruh terhadap niat seseorang untuk melakukan whistleblowing.

Banyak penelitian tentang whistleblowing yang mengunakan prosocial organizational behavior theory untuk menjelaskan komitmen organisasi. Menurut Brief dan Motowidlo (1986) prosocial organizational behavior theory sebagai perilaku/tindakan yang dilakukan oleh anggota sebuah organisasi terhadap individu, kelompok, atau organisasi yang ditunjuk untuk meningkatkan kesejahteraan individu, kelompok, atau organisasi tersebut. Dalam hal ini prosocial organizational behavior theory telah menegaskan bahwa tindakan whistleblowing seorang pegawai menunjukkan bentuk komitmen pegawai tersebut untuk melindungi organisasinya dari ancaman hal-hal yang tidak etis atau ilegal. Maka dapat disimpulkan bahwa prosocial behavior dapat menjadi teori yang mendukung terjadinya whistleblowing. Berdasarkan hasil penelitian sebelumnya, maka hipotesis ketiga yang diajukan adalah:

H3. Komitmen organisasi berpengaruh positif terhadap niat melakukan whistleblowing.

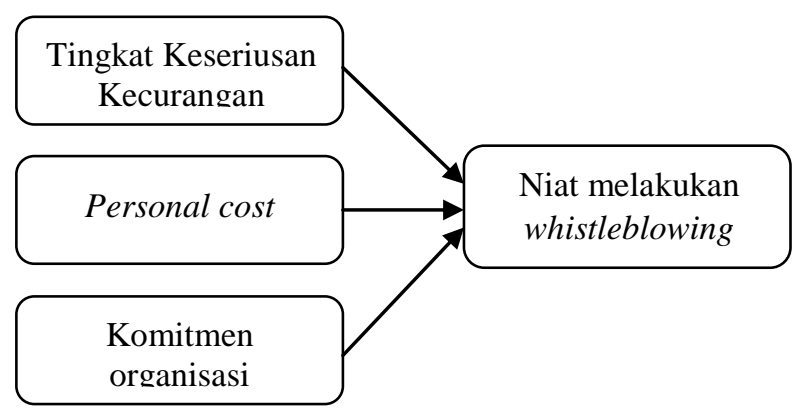

Gambar 1. Model Penelitian

\section{Metode Penelitian}

Penelitian ini merupakan penelitian kuantitatif dengan data survei dalam bentuk kuisioner. Sampel berasal dari 53 Pegawai Negri Sipil Badan Perencanaan Pembangunan Daerah Kota Pekanbaru. Analisis data menggunakan regresi linier berganda dengan bantuan program aplikasi SPSS (statistic package for social science).

\subsection{Pengukuran Variabel}

Tingkat keseriusan kecurangan merupakan ukuran seberapa besar keseriusan kecurangan yang dapat merugikan organisasi. Variabel ini diukur menggunakan indikator dari Bagustianto dan Nurkholis (2015) dan Winardi (2013). Setiap responden akan diminta untuk menjawab pernyataan tersebut menggunakan skala interval 1-5, dengan keterangan 1 sangat tidak setuju, 2 tidak setuju, 3 kurang setuju, 4 setuju, dan 5 sangat setuju. Selanjutnya, variabel personal cost merupakan pandangan pegawai terhadap risiko pembalasan/balas dendam atau sanksi dari 
anggota organisasi, yang dapat mengurangi niat pegawai untuk melaporkan wrongdoing/kecurangan Schultz et al. (1993). Variabel ini akan diukur dengan indikator dari Septianti (2013). Komitmen organisasi adalah suatu sikap yang merefleksikan tingkat loyalitas seorang anggota organisasi terhadap organisasinya (Abdullah, 2017). Variabel ini akan diukur dari beberapa indikator yang telah dilakukan dalam penelitian Kanning dan Hill (2013). Terakhir, whistleblowing merupakan tindakan dari seseorang pegawai (atau mantan pegawai) untuk, mengungkap apa yang ia percaya sebagai perilaku ilegal atau tidak etis kepada manajemen yang lebih tinggi/manajemen puncak (internal whistleblowing) atau kepada otoritas/pihak berwenang diluar organisasi maupun kepada publik (eksternal whistleblowing) (Bouville, 2007). Variabel ini diukur menggunakan indikator dari Bagustianto dan Nurkholis (2015).

\section{Hasil Penelitian dan Pembahasan}

\subsection{Gambaran Umum Responden}

Berdasarkan tabel 1 dapat diketahui bahwa responden dalam penelitian ini berdasarkan kelompok gender didominasi oleh laki-laki yaitu sebesar $54.7 \%$ dan sisanya sebesar $45.3 \%$ adalah perempuan. Sedangkan berdasarkan kelompok umur, mayoritas responden berumur dalam kisaran 31-40 tahun (37.7\%). Hal ini berarti bahwa responden dalam penelitian ini tergolong pada kategori umur yang sangat produktif. Jika dilihat dari tingkat pendidikan responden, mayoritas bergelar sarjana yaitu sebesar $56,6 \%$. Hal ini mengindikasikan bahwa mayoritas responden dalam penelitian ini memiliki kualifikasi pendidikan yang cukup baik dan mumpuni sesuai dengan bidang ilmunya masing-masing. Selanjutnya, berdasarkan pengalaman kerja, sebanyak $50,9 \%$ responden telah bekerja lebih dari lima belas tahun. Hal ini berarti bahwa responden dalam penelitian ini telah bekerja cukup lama dan memiliki pengetahuan yang sesuai untuk menjawab kuisioner penelitian yang diberikan (lihat tabel 1).

Tabel 1: Karakteristik Demografi Responden (N=53)

\begin{tabular}{|c|c|c|c|c|c|}
\hline Karakteristik Responden & Jumlah & $\%$ & Karakteristik Responden & Jumlah & $\%$ \\
\hline Gender: & & & Jenjang Pendidikan: & & \\
\hline - Laki-Laki & 29 & $54,7 \%$ & - Doktor & 2 & $3,8 \%$ \\
\hline - Perempuan & 24 & $45,3 \%$ & - Master & 14 & $26,4 \%$ \\
\hline Kelompok Umur: & & & - Sarjana & 30 & $56,6 \%$ \\
\hline - $\quad<30$ Tahun & 0 & 0 & - Diploma & 2 & $3,8 \%$ \\
\hline - $\quad 31-40$ Tahun & 20 & $37,7 \%$ & - $\quad$ SMA & 5 & $9,4 \%$ \\
\hline - 41-50 Tahun & 17 & $32,1 \%$ & Lama Bekerja: & & \\
\hline - > 50 Tahun & 16 & $30,2 \%$ & - $\quad<2$ & 0 & $0 \%$ \\
\hline Jabatan: & & & - $2-5$ & 5 & $9,4 \%$ \\
\hline - Eselon I & 0 & $0 \%$ & - $6-10$ & 10 & $18,9 \%$ \\
\hline - Eselon II & 5 & $9,4 \%$ & - $11-15$ & 11 & $20,8 \%$ \\
\hline - Eselon III & 37 & $69,8 \%$ & - $>15$ & 27 & $50,9 \%$ \\
\hline - Eselon IV & 11 & $20,8 \%$ & & & \\
\hline
\end{tabular}

Tabel 2: Statistik Deskriptif

\begin{tabular}{lccccc}
\hline & $\mathrm{N}$ & Min & Max & Mean & Std. Deviation \\
\hline Tingkat Keseriusan Kecurangan & 53 & 8 & 20 & 15.15 & 2.957 \\
Personal Cost & 53 & 16 & 29 & 22.11 & 3.030 \\
Komitmen Organisasi & 53 & 12 & 20 & 16.19 & 2.149 \\
Niat Melakukan Whistleblowing & 53 & 10 & 25 & 19.53 & 3.434 \\
Valid N (listwise) & 53 & & & & \\
\hline
\end{tabular}

Berdasarkan tabel 2 tentang hasil uji statistik deskriptif menjelaskan bahwa variabel tingkat keseriusan kecurangan memiliki nilai rata-rata 15.15 dan standar deviasi sebesar 2,957, variabel personal cost memiliki nilai rata-rata 22.11 dan standar deviasi sebesar 3.030, variabel komitmen organisasi memiliki nilai rata-rata 16,19 dan standar deviasi sebesar 2,149, dan variabel niat melakukan whistleblowing memiliki nilai rata-rata 19,53 
dan standar deviasi sebesar 3.434. Berdasarkan angka tersebut dapat disimpulkan bahwa untuk variabel variabel personal cost rata-rata responden menjawab kurang setuju. Sementara untuk tingkat keseriuasan kecurangan dan komitmen organisasi serta niat melakukan whistleblowing rata-rata jawaban responden adalah setuju.

\subsection{Hasil Analisis Data}

Berdasarkan hasil analisis data menggunakan software SPSS dapat diketahui bahwa semua data dalam penelitian ini telah memenuhi asumsi untuk dilakukan pengujian regresi linier berganda. Hasil uji KolmogrovSminov menunjukkan bahwa nilai signifikansi sebesar $0.632(>0,05)$ sehingga memberikan kesimpulan bahwa sebaran data telah memenuhi asumsi normalitas. Kemudian hasil pengujian heteroskedastisitas menggunakan uji
Glejser menunjukkan bahwa variabel komitmen organisasi memiliki nilai signifikansi 0.483 , personal cost memiliki nilai signifikansi 0.684 , dan tingkat keseriusan kecurangan memiliki nilai signifikansi 0.982 , sehingga dapat disimpulkan bahwa semua variabel tidak terjadi gejala heteroskedastisitas. Selanjutnya hasil uji multikolinieritas ditunjukkan dengan nilai tolerance untuk tingkat keseriusan kecurangan 0,796 serta VIF 1,257, variabel personal cost dengan nilai tolerance 0,987 serta VIF 1,013 , dan variabel komitmen organisasi dengan nilai tolerance 0,804 serta VIF 1,243. Dengan demikian, dapat disimpulkan bahwa model persamaan regresi tidak terdapat masalah multikolonearitas dan dapat dianalisis lebih lanjut. Selanjutnya, hasil pengujian hipotesis menggunakan analisis regresi berganda ditunjukkan pada tabel 3 berikut ini:

Tabel 3: Hasil Uji Regresi Linier Berganda

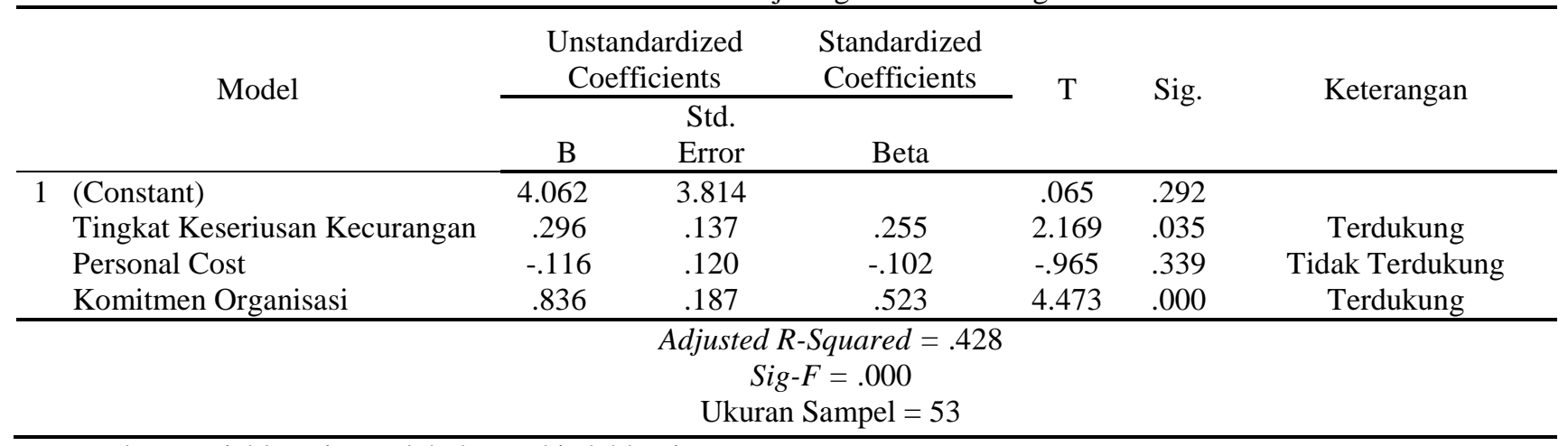

Dependent Variable: Niat Melakukan Whistleblowing

\subsection{Pengaruh tingkat keseriusan kecurangan terhadap niat melakukan whistleblowing}

Berdasarkan hasil uji hipotesis menunjukan bahwa variabel tingkat keseriusan kecurangan mempunyai signifikansi 0,035 lebih kecil dari 0,05 . Hal ini memberikan arti bahwa hipotesis pertama diterima. Hasil ini mengindikasikan bahwa tingkat keseriusan kecurangan berpengaruh terhadap niat melakukan whistleblowing. Semakin serius tingkat kecurangan yang dilakukan oleh salah satu anggota organisasi, maka kecenderungan untuk melakukan wistleblowing akan semakin besar. Tingkat keseriusan kecurangan adalah ukuran seberapa besar keseriusan kecurangan yang dapat merugikan organisasi. Anggota organisasi yang mengamati adanya dugaan pelanggaran akan lebih mungkin untuk melakukan whistleblowing jika pelanggaran tersebut serius (Near dan Miceli, 1985). Menurut Theory of planned behavior menjelaskan bahwa niat diasumsikan untuk menangkap faktor-faktor motivasi yang mempengaruhi sebuah perilaku, yang ditunjukkan oleh seberapa keras usaha yang direncanakan seorang individu untuk mencoba melakukan perilaku tersebut. Jika seseorang yang melihat adanya dugaan kecurangan yang berdampak buruk/serius bagi organisasinya, maka akan tumbuh niat untuk melakukan whistleblowing. Hasil penelitian ini sejalan dengan penelitian Winardi (2013) yang menjelaskan bahwa tingkat keseriusan kecurangan dapat mempengaruhi niat melakukan whistleblowing dengan mengunakan theory of planned behavior. Ketika tingkat keseriusan kecurangan itu 
tinggi maka niat melakukan whistleblowing akan semakin tinggi.

\subsection{Pengaruh Personal cost terhadap niat melakukan whistleblowing}

Berdasarkan hasil uji hipotesis dapat diketahui bahwa hasil pengujian variabel personal cost mempunyai signifikan 0,339 lebih besar dari 0,05. Hal ini memberikan arti bahwa hipotesis kedua tidak terdukung. Temuan ini mengindikasikan bahwa personal cost tidak berpengaruh terhadap niat PNS melakukan tindakan whistleblowing. Temuan ini memberikan kesimpulan bahwa PNS Bappeda tidak mempertimbangkan personal cost sebagai faktor yang akan mempengaruhi niatnya untuk melakukan atau tidak melakukan tindakan whistleblowing. Hasil ini didukung oleh studi yang dilakukan oleh Septianti (2013) dan Bagustianto dan Nurkholis (2015) bahwa personal cost tidak berpengaruh terhadap niat PNS melakukan tindakan whistleblowing. Personal cost adalah pandangan pegawai terhadap tindakan pembalasan dendam dari anggota organisasi, yang dapat mengurangi niat pegawai untuk melakukan whistleblowing (Schultz et al, 1993). Menurut Theory of planned behavior menjelaskan bahwa niat diasumsikan untuk menangkap faktor-faktor motivasi yang mempengaruhi sebuah perilaku, yang ditunjukkan oleh seberapa keras usaha yang direncanakan seorang individu untuk mencoba melakukan perilaku tersebut. Semakin besar persepsi personal cost, maka semakin rendah niat untuk melaporkan tindakan kecurangan, sebaliknya semakin menurun persepsi personal cost maka semakin tinggi niat untuk melaporkanya. Tidak berpengaruhnya personal cost terhadap niat melakukan whistleblowing karena pegawai dari suatu organisasi sudah siap mengambil resiko apabila dia mendapatkan pembalasan dendam dari rekan kerjanya (Nugrohaningrum, 2018).

\subsection{Pengaruh komitmen organisasi terhadap niat melakukan whistleblowing}

Berdasarkan hasil uji hipotesis yang dilakukan menunjukkan bahwa komitmen organisasi mempunyai signifikansi 0.000 lebih kecil dari 0.05. Hal ini memberikan arti bahwa hipotesis ketiga terdukung, sehingga dapat dikatakan bahwa komitmen organisasi berpengaruh terhadap niat melakukan whistleblowing. Hasil ini sejalan dengan konsep prosocial organizational behavior bahwa tindakan whistleblowing merupakan perilaku sosial positif yang dapat memberikan manfaat bagi organisasi dalam bentuk melindungi dari bahaya kecurangan. Semakin tinggi loyalitas pegawai terhadap organisasinya maka semakin tinggi juga tindakan whistleblowing karena mereka tidak ingin melihat organisasinya hancur oleh orang yang tidak bertanggungjawab. Hasil ini memberikan penjelasan bahwa jika seorang pegawai memiliki komitmen yang tinggi teradap organisasinya, maka pegawai tersebut akan senantiasa melakukan apa saja untuk melindungi organisasinya dari kehancuran. Semakin tinggi komitmen yang dimiliki seseorang maka akan meningkatkan niat seseorang untuk melaporkan tindakan kecurangan yang diketahui untuk tujuan meminimalisir kecurangan yang terjadi dalam organisasi. Hasil penelitian ini sejalan dengan temuan Bagustianto dan Nurkholis (2015) yang menyatakan bahwa komitmen organisasi berhubungan positif terhadap niat melakukan whistleblowing. Hal ini dikarenakan pegawai yang memiliki komitmen yang tinggi teradap organisasinya akan melakukan tindakan prososial dan melaporkan segala bentuk tindakan kecurangan yang dapat merugikan organisasi.

\section{Kesimpulan}

Hasil pengujian data empiris menunjukkan bahwa tingkat keseriusan kecurangan dan komitmen organisasi berpengaruh terhadap kecenderungan untuk melakukan whistleblowing. Hasil ini memberikan kesimpulan bahwa semakin serius tingkat kecurangan yang dilakukan oleh salah satu anggota organisasi, maka kecenderungan untuk melakukan wistleblowing akan semakin besar. Begitu juga ketika seorang pegawai memiliki komitmen yang tinggi teradap organisasinya, maka pegawai tersebut akan melakukan tindakan prososial dan melaporkan segala bentuk tindakan kecurangan yang dapat merugikan organisasi. Namun, hasil penelitian ini tidak menemukan adanya pengaruh personal cost terhadap kecenderungan 
melakukan whistleblowing. Temuan ini memberikan kesimpulan bahwa PNS Bappeda tidak mempertimbangkan personal cost sebagai faktor yang akan mempengaruhi niatnya untuk melakukan atau tidak melakukan tindakan whistleblowing. Hal ini karena pegawai dari suatu organisasi sudah siap mengambil resiko apabila dia mendapatkan pembalasan dendam dari rekan kerjanya.

Penelitian ini meberikan kontribusi dalam pengembangan literatur dan penjelasan theory of planned behavior dan prosocial organizational behavior theory yaitu seseorang akan melaporkan tindakan kecurangan yang terjadi diorganisasinya dengan mengacu pada kemudahan atau kesulitan yang dihadapi untuk melakukan perilaku tersebut. Ini terlihat bahwa jika tingkat keseriusan kecurangan tinggi maka niat melakukan whistleblowing akan meningkat. Semakin serius tingkat kecurangan yang dilakukan oleh salah satu anggota organisasi maka niat untuk melakukan whistleblowing akan meningkat. Selain itu, penelitian ini memberikan implikasi praktis kepada organisasi sektor publik agar membuat suatu kebijakan yang bisa meningkatkan niat PNS untuk berani dan tidak ragu melakukan whistleblowing karena bisa meminimalkan tindakan kecurangan. Misalnya melalui mekanisme pemberian penghargaan kepada yang melaporkan adanya tindakan kecurangan atau memperbaiki whistleblowing system sehingga pegawai tidak ragu melakukan tindakan whistleblowing karena identitasnya dapat tersembunyi dan aman dari resiko pembalasan dendam.

Penelitian ini memiliki beberapa keterbatasan. Pertama, sampel penelitian ini terbatas pada satu organisasi sektor publik yaitu Badan Perencanaan dan Pembangunan Daerah Kota Pekanbaru. Sehingga hasil penelitian belum tentu bisa digeneralisasi pada organisasi lain. Oleh karena itu, penelitian lanjutan perlu memperluas sampel pada lebih dari satu organisasi sektor publik. Kedua, Penelitian ini hanya meneliti tiga variabel, sehingga belum bisa menangkap semua faktor yang kemungkinan dapat mempengaruhi kecenderungan pegawai untuk melakukan whistleblowing. Penelitian lanjutan disarankan untuk meneliti variabel lain, misalnya saluran pelaporan dan faktor dukungan rekan kerja/atasan yang kemungkinan dapat mempengaruhi whistleblowing.

\section{Daftar Pustaka}

Abdullah, M. W. (2017). Determinan Intensi Auditor Melakukan Tindakan Whistle-Blowing Dengan Perlindungan Hukum Sebagai Variabel Moderasi. Jurnal Ekonomi Dan Keuangan, 1(3), pp. 385-407. Https://Doi.Org/10.24034/J25485024.Y2017.V 1.I3.2096.

Ahyaruddin, M. \& Asnawi, M. (2017). Pengaruh Moral Reasoning dan Ethical Environment Terhadap Kecenderungan Untuk Melakukan Whistleblowing. Jurnal Akuntansi \& Ekonomika, 7(1). pp. 1-12.

Ajzen, I. (1991). The Theory Of Planned Behavior. Organizational Behavior And Human Decision Processes, 50(2). pp. 179-211.

Aliyah, S. (2015). Analisis Faktor-Faktor Yang Mempengaruhi Niat Pegawai Dalam Melakukan Tindakan Whietle-Blowing. Jurnal Dinamika Dan Bisnis, 12(2), 173-189.

Bagustianto, R. \& Nurkholis. (2015). FaktorFaktor Yang Mempengaruhi Minat Pegawai Negeri Sipil (PNS) Untuk Melakukan Tindakan Whistle-Blowing (Studi Pada PNS BPK RI). Ekuitas: Jurnal Ekonomi dan Keuangan, 19(2), pp. 276-295.

Bouville, M. (2007). Whistle-Blowing And Morality. Journal Of Business Ethics, (81), 579-585. Https://Doi.Org/10.1007/S10551007-9529-7

Brief, A. P., \& Motowidlo, S. J. (1986). Prosocial Organizational Behaviors. The Academy of Management Review, Vol. 11.

Dozier, J. B. \& Miceli, M. P. (1985). Potential Predictors Of Whistle-Blowing: A Prosocial Behavior Perspective. Academy Of Management Review, 10(4), 823-836.

Indonesia Corruption Watch (ICW). (2017). Annual Report 2016 Indonesia Corruption Watch Menyemai Semangat Antikorupsi. diakses melalui www.antikorupsi.org pada tanggal 23 Februari 2019.

Kanning, U. P., \& Hill, A. (2013). Validation Of The Organizational Commitment Questionnaire (Ocq) In Six Languages. Journal Of Business And Media Psychology, 4(2), 11-20.

Liyanarachchi, G., \& Newdick, C. (2009). The Impact Of Moral Reasoning And Retaliation On Whistle-Blowing: New Zealand Evidence. Journal Of Business Ethics, 89(1), 37-57. Https://Doi.Org/10.1007/S10551-008-9983-X 
Near J. P \& Miceli, M. P. (1985). Organizational Dissidence: The Case Of Whistle-Blowing. Journal Of Business Ethics, 4(1), 1-6.

Nugrohaningrum, D. (2018). Analisis FaktorFaktor yang Mempengaruhi Niat Pegawai Pemda Untuk Melakukan Whistleblowing. Skripsi Fakultas Ekonomi Universitas Islam Indonesia. Tidak Dipublikasikan.

Schultz-Jr., Joseph J., Johnson, Douglas A., Morris, Deigan Dan Dyrnes, S. (1993). An Investigation Of The Reporting Of Questionable Acts In An International Setting. Journal Of Accounting Research, 31, 75-103.

Septianti, W. (2013). Pengaruh Faktor
Organisasional, Individual, Situasional, Dan Demografis Terhadap Niat Melakukan Whistleblowing Internal. Prosiding. Simposium Nasional Akuntansi XVI Manado.

Setyawati, Ardiyani I. K., Sutrisno C.R. (2015). Faktor-Faktor Yang Mempengaruhi Niat Melakuakn Whistleblowing Internal. Jurnal Ekonomi Bisnis, 17(2).

Winardi, R. D. (2013). The Influence Of Individual And Situational Factors On Lower-Level Civil Servants' Whistle-Blowing Intention In Indonesia. Journal Of Indonesian Economy And Business, 28(3), 361-376. 